\title{
Distribution pattern of tree species from tropical to temperate regions in Makawanpur district, central Nepal
}

\author{
S. Bhattarai ${ }^{1 *}$, B. Bhatta ${ }^{1}$ and R. Tamang ${ }^{2}$
}

\begin{abstract}
Tree species are the dominant component of forest ecosystems which influence most structural and functional attributes of these ecosystems. This study aims to document distribution pattern of forest types and their composition from tropical region at Hetauda (550 $\mathrm{m}$ asl) to temperate region above Simbhangyang ( $2500 \mathrm{~m}$ asl) of Makawanpur district, central Nepal. The carbon stock in the living biomass of tree species was estimated using an allometric equation while the biodiversity index was calculated using Shannon-Wiener Biodiversity index. A total of 62 species of trees belonging to 51 genera was recorded. Shorea forest was dominant in lower elevation while Quercus forest, Alnus-Rhododendron, Quercus-Lyonia and Quercus-Symplocos forests at higher elevation. Similarly, Castanopsis tribuloides has the widest distribution range (570 m to $2240 \mathrm{~m}$ asl) followed by Shorea robusta, Lagerstroemia parviflora, Trichilia connaroides, Syzigium jambos, Castanopsis indica, Schima wallichii etc. The highest number of tree species was recorded at $550 \mathrm{~m}$ elevation. Estimated carbon stocks were ranged from $0.85-53.37 \mathrm{t} / \mathrm{ha}$ with the mean value $24.98 \mathrm{t} / \mathrm{ha}$. The values of Shannon-Wiener Biodiversity index ranged from 1.23-2.78. There was positive relationship between carbon stock and biodiversity index $\left(R^{2}=0.40, p=0.03\right)$. People have been practicing community forest management to support sustainability of harvesting in the study area.
\end{abstract}

Keywords: Allometric equation, biodiversity index, Daman, forest, Hetauda, species

$\mathrm{V}$ egetation is the reflection of physiographic and climatic condition of an area. Nepal is a small country in terms of area, though it is rich in floristic composition. Being a mountainous country, altitudinal gradient is quite common feature of physiography which ultimately creates microclimatic condition that supports vegetation diversity. Floristic or inventory is the systematic enumeration and documentation of all plant species in a given geographic region and ideally provides keys, description and often illustration (Naik, 1998; Simpson, 2006). Exploration is the most important step of systematic study. In montane Nepal, altitude and aspect are the paramount importance in determining the type of forest found at particular place (Stainton, 1972).

Altitude, one of the major factors determining the climatic condition, affects directly the distribution of species of an area. Along with the increasing altitudinal gradient, the temperature and rainfall differ markedly so the species should adapt to the particular condition to sustain their life. However, majority of the species cannot adapt the major change in climatic conditions and become restricted to a limited elevation.

Forests being standing stores of sequestered atmospheric carbon can serve as valuable carbon pool. It is thus, the global communities become progressively more concerned with forest ecosystem as a tool to mitigate the impacts of climate change. This study focused on the distribution pattern of forest types and their composition along altitudinal gradient.

\section{Materials and methods}

\section{Study area}

This research work was carried out from Hetauda to Simbhangyang of Makawanpur district. All

1. Faculty of Forestry, Agriculture and Forestry University, Hetauda, Nepal, "E-mail: sbhattarai@afu.edu.np

2. District Plant Resources Office, Makawanpur 
together 12 spots were fixed at different altitude $(550 \mathrm{~m}$ to $2500 \mathrm{~m}$ ) and forest types from Hetauda to Simbhangyang to cover maximum tree species as far as possible. The study area comprises tropical, subtropical and temperate climatic zones (DDC, 2015). Tropical zone comprises Sal and riverine forests at southern lower belts where Shorea robusta, Terminalia chebula, Terminalia bellirica, Adina cordifolia, Acacia catechu, Dalbergia sissoo, Bombax ceiba etc. flourish very well. Subtropical region consists of mainly Schima-Castanopsis, Chir pine and Alder forests comprising Schima wallichii, Castanopsis indica, Castanopsi stribuloides, Pinus roxburghii as dominating species. Similarly, Rhododendron arboreum, Myrica esculenta, Lyonia ovalifolia, Quercus lanata as dominating species in the temperate forests. Sample plots of the study area is given in figure 1.
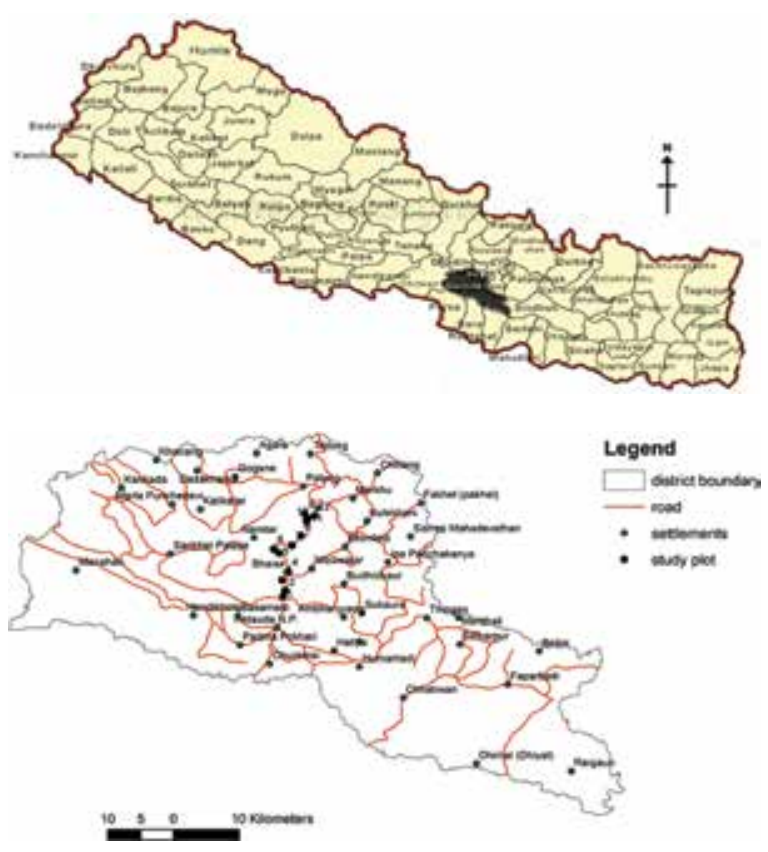

Fig. 1: Dots representing the sample plots of study area

\section{Sampling design}

A stratified random sampling method was used for locating the sample plots. The forest types were considered as strata. Altogether, 12 spots were fixed at different altitude (550 $\mathrm{m}$ to $2500 \mathrm{~m}$ ) and forest types from Hetauda to Simbhangyang to cover maximum tree species as far as possible. At each spot, a square quadrate of $20 \mathrm{~m} \times 20 \mathrm{~m}$ was set up. Then, each sample plot was characterized by altitude, slope, aspect, crown canopy cover
(\%) and geographic location.

\section{Data collection}

Diameter at breast height (DBH) of tree standing at least a $1.3 \mathrm{~m}$, and the height of individual trees of $\leq 5 \mathrm{~cm} \mathrm{DBH}$ were measured. Species and their distribution were identified using relevant literature like Hara et al. (1978, 1979, 1982), Malla et al. (1986), Pande (1967), Press et al. (2000), Stainton (1988), Suwal (1969) while a few specimens were also confirmed by tallying with specimens deposited at KATH.

\section{Data analysis}

Distribution pattern of forest types and tree species along altitudinal gradient was analyzed using Detrended Correspondence Analysis (DCA) (Hill and Gauch, 1980). Since the mean annual precipitation of the study area is $2206 \mathrm{~mm}$, the carbon stock in the living biomass of tree species was estimated using an allometric model for 'moist forest' (annual precipitation 1500-3500 $\mathrm{mm}$ ) developed by Chave et al. (2005) while the biodiversity index was calculated using ShannonWiener biodiversity index as -

\section{Allometric equation - \\ The aboveground biomass $(\mathrm{kg})$ of a tree $=$ $0.0509 \times \boldsymbol{\rho} \boldsymbol{D}^{2} \mathrm{H}$}

Where, $\rho$ is wood density $\left(\mathrm{g} \mathrm{cm}^{-3}\right), \mathrm{H}$ is height of tree $(\mathrm{m}), \mathrm{D}$ is diameter of tree at breast height $(\mathrm{cm})$ as proposed in forest carbon stock measurement guidelines (Subedi et al., 2010). For dry wood density, the global database was used (Zanne et al., 2009). The biomass stock $\left(\mathrm{kg} / \mathrm{m}^{2}\right)$ of each sampling plot was obtained by dividing the sum of all the individual biomass by the area of sampling plot $\left(400 \mathrm{~m}^{2}\right)$ and converted to tonnes per hectare. Later, biomass value was converted into carbon stock by multiplying with carbon fraction of 0.47 (IPCC, 2006).

Total biomass $=$ Above ground biomass $\times 1.15$

Carbon stock $=$ Total biomass $\times 0.47$

Shannon-Wiener biodiversity index-

$\mathrm{H}^{\prime}=-\Sigma$ pi lnpi

Where, $\mathrm{H}^{\prime}$ is the diversity index, pi is the proportion of $i^{\text {th }}$ species individuals to total species individuals, and $\ln$ is natural logarithm. 


\section{Results and discussion}

Sixty two (62) tree species belonging to fifty one(51) genera was recorded. Among them, Albizia, Quercus and Terminalia were the largest genera with three species each followed by Castanopsis, Pinus, Premna, Rhus and Vibernum with two species each while remaining genera were monotypic ones (Fig. 2).

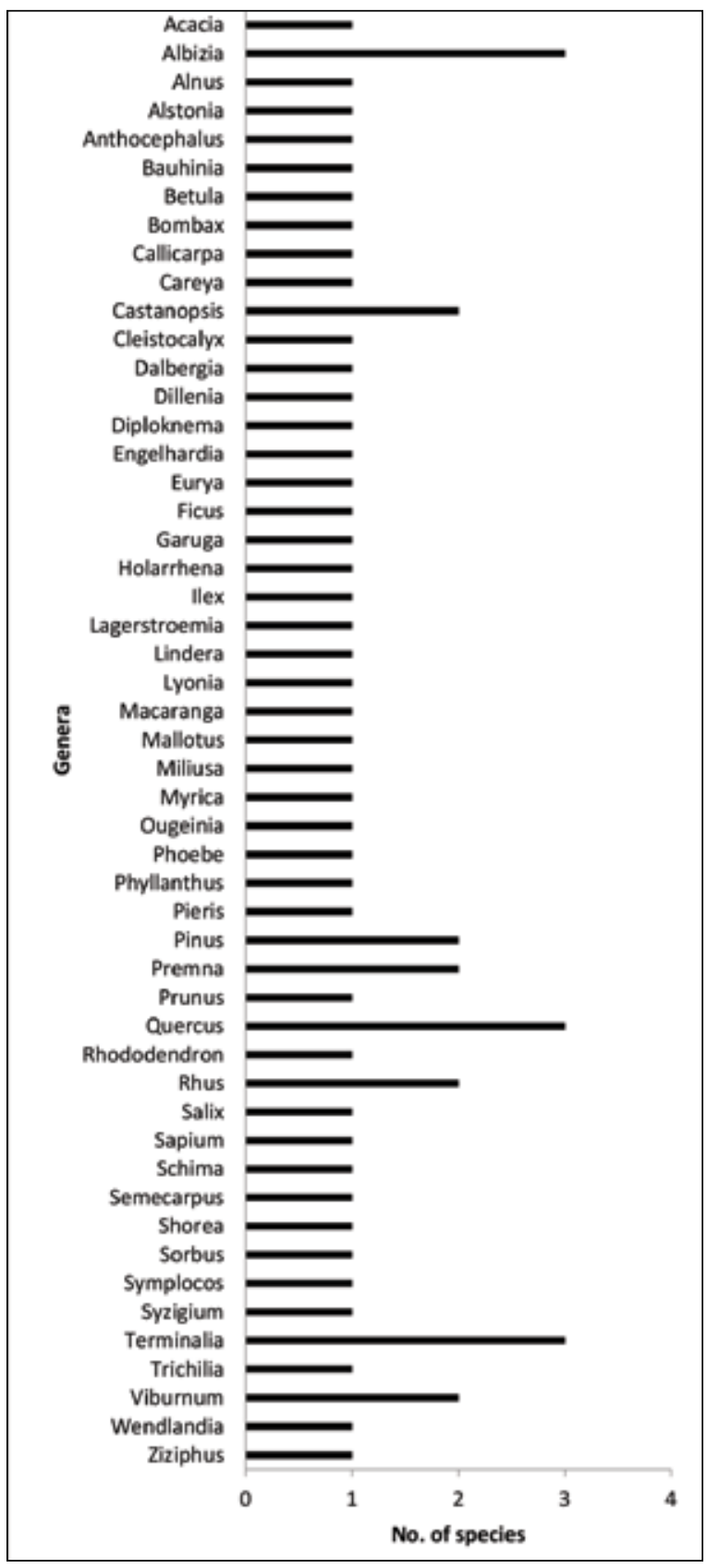

Fig. 2. Number of species per genera

\section{Distribution pattern of forest along altitudinal gradient}

The DCA axis I and II represent elevation and forest type, respectively. Species found towards the left and negative end of DCA axis I like Albizia procrea, S. robusta, Trichilia connaroides are highly abundant at lower elevation representing Shorea dominant forest (Fig. 3). The positive and right end of DCA axis I represents species abundant at high elevation. Quercus forest, AlnusRhododendron, Quercus-Lyonia and QuercusSymplocos forest were dominant at higher elevation. Similarly, Pinus and Alnus-Macaranga were common at middle elevation (Fig. 3).

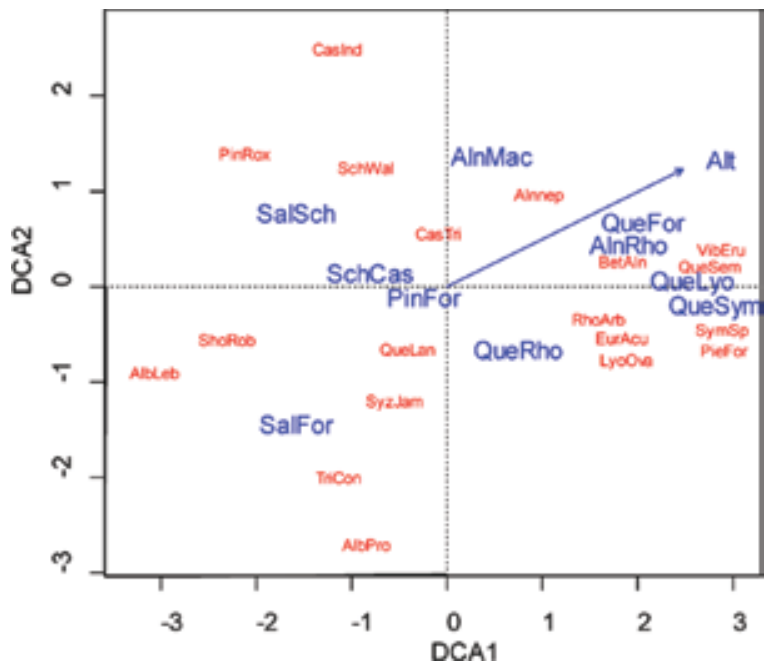

Fig. 3: DCA diagram showing environmental variation (elevation) represented by arrow and nominal variable (forest types) represented by bold words

\section{Diversity index, carbon stock and altitude}

The carbon stock in this study ranged from $0.85-53.37 \mathrm{t} / \mathrm{ha}$ with the mean value $24.98 \mathrm{t} /$ ha. Similarly, Shannon's diversity index ranged from $1.23-2.78$. The diversity index of species and carbon stock significantly decreased along altitudinal gradient (Fig. 4 and Fig. 5). However, there was no significant difference in density along elevational gradient.

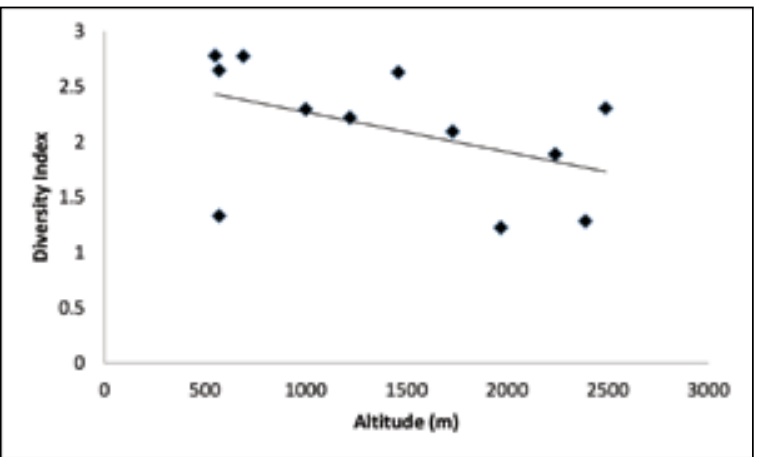

Fig. 4: Relationship between altitude and species diversity index 


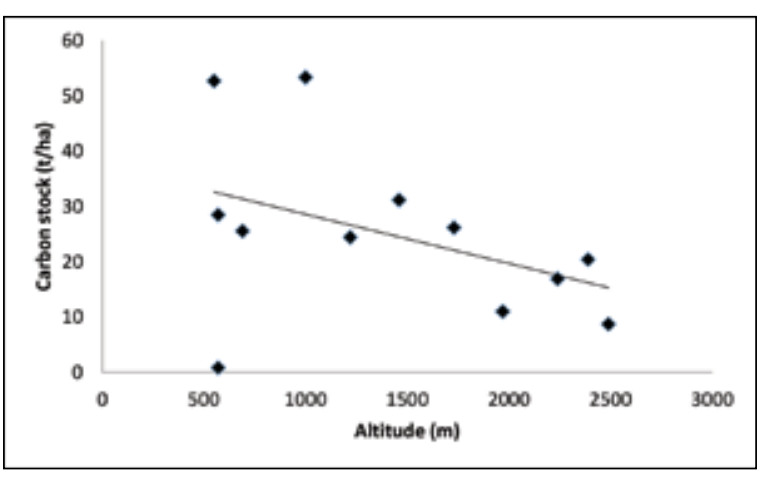

\section{Fig 5: Relationship between altitude and} carbon stock

\section{Forest carbon stock and diversity index}

The relationship between Shannon's diversity index and carbon stock in these plant communities was significant with a positive linear relationship $\left(\mathrm{R}^{2}=0.40, \mathrm{p}=0.03\right)$. Both carbon stock and Shannon-Weiner diversity index were gradually decreased with increase in elevation (Fig. 6).

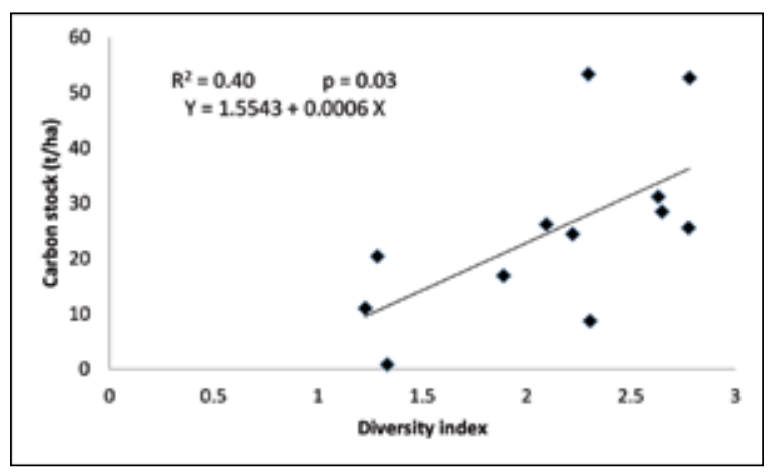

Fig. 6: Relationship between carbon stock and diversity index

Vegetation of an area is largely affected by various factors including temperature, rainfall, humidity, and soil characters, etc. which in turn get affected by altitude. The study area ranging altitudinal gradient from $550-2500 \mathrm{~m}$ provides a unique habitat for both flowering and non-flowering plants. In this study, Albizia, Alstonia, Mallotus, Shorea, Garuga, Terminalia, Holarrhena, etc. were the common species at lower elevation whereas Acacia, Dalbergia, Bombax, etc. were common along river side. Similarly, Betula, Quercus, Pinus, Sorbus, Rhus, Macaranga, Prunus, Symplocos, etc. represented the Mid-hill forests.
Makawanpur district comprises 1068 species of flowering plants consisting of 210 tree species, 211 shrubs and remaining herbs (Chapagain et al., 2016). The study area represents a total number of 62 tree species belonging to 51 genera i.e. about one third of the total number of tree species of Makawanpur district. Shorea forest is dominant at lower elevation followed by Pinus and AlnusMacaranga forest at the middle elevation and Quercus, Alnus-Rhododendron and QuercusLyonia forest at the higher elevation. Similarly, C. tribuloids had the widest distribution range (570 $\mathrm{m}$ to $2240 \mathrm{~m}$ asl) followed by S. robusta, $L$. parviflora, T. connaroides, $S$. jambos, $C$. indica, S. wallichii, Wendlandia coriacea, L. ovalifolia and Alnus nepalensis.

Though the standing biomass of tree species tended to concentrate in species of large trees, it seems that overall biomass values differed more due to species richness than species composition. A positive relation was found between Shannon's diversity index and carbon stock $\left(\mathrm{R}^{2}=0.40, \mathrm{p}=0.03\right)$. The lower belt was suitable for biodiversity to flourish well thus preserving much biomass and also carbon stock. The result showed that both biodiversity index and carbon stock were significantly higher in lower elevation and decreased along altitudinal gradient. The diversity-biomass relationship is affected by the environment (Guo and Berry, 1998). When environments are homogeneous, linear relationships are present, and when environments are heterogeneous, inverted U-type curvilinear relationships occur. Although hump-shaped or unimodal relationships between biomass and species diversity (Waide et al., 1999; Roy, 2001; Alhamad et al., 2010) have been frequently observed in mature vegetation, recent findings show positive relationship in establishing vegetation (Hooper et al., 2005; Spehn et al., 2005). This mechanism of changing relationship has been mainly discussed in terms of facilitation and competition i. e. when biomass is relatively low, diversity increases due to interspecific facilitation; whereas when biomass accumulates to a certain level, competition leads to lower diversity (Guo and Berry, 1998; Weiner and Thomas, 2001; Guo, 2007).

\section{Conclusion}

In the present study, the tropical forest represents the greatest value of both diversity index and 
carbon stock whereas these values get decreased along elevational gradient. This also indicates that species richness is positively related with biomass and carbon stock value thus conserving biodiversity is not only important in terms of conservation but also in mitigating the negative impacts of climate change issues. In other words, the present result has provided empirical support for the argument that increases in the biodiversity index could increase carbon stock if other anthropogenic and environmental factors are not limiting.

\section{References}

Alhamad, M. N., Oswald, B. P., Bataineh, M. M., Alrababah, M. A. and Gharaibeh, M. M. 2010. Relationships between Herbaceous Diversity and Biomass in Two Habitats in Arid Mediterranean Rangeland. Faculty Publication (Stephen F. Austin State University) 12.

Chapagain, N. H., Pandit, R. K. and Tamang, R. 2016. Flowering Plants of Makawanpur. District Plant Resources Office, Makawanpur, Nepal.

Chave, J., Andalo, C., Brown, S., Cairns, M. A., Chambers, D., Eamus, D., . . . Yamakura, T. 2005. Tree allometry and improved estimation of carbon stocks and balance in tropical forests. Oecologia, 145: 87-99.

DDC.2015. District Development Plan of Makwanpur. District Development Committee, Makwanpur, Hetauda, Nepal.

Guo, Q. and Berry, W. L. 1998. Species richness and biomass: Dissection of the humpshaped relationships. Ecology79 (7): 2555-2559.

Guo, Q. 2007. The diversity-biomassproductivity relationships in grassland management and restoration. Basic and Applied Ecoloty 8 (3):199—208.

Hara, H., Chater, A.O. and Williams, L. H. J.1978. An Enumeration of Flowering Plants of Nepal. Vol 1. British Museum (Natural History), London, UK.
Hara, H., Chater, A.O. and Williams, L. H. J.1979. An Enumeration of Flowering Plants of Nepal .Vol 2. British Museum (Natural History), London, UK.

Hara, H., Chater, A. O. and Williams, L. H. J.1982. An Enumeration of Flowering Plants of Nepal. Vol 3. British Museum (Natural History), London, UK.

Hill, M. O. and Gauch, H. G. 1980. Detrended correspondance analysis: an improved ordination technique. Vegetation 42 (13): $47-58$.

Hooper, D. U., Chapin, F. S. III, Ewel, J. J., Hector, A., Inchausti, P. and Lavorel, S., Lawton, J. H., Lodge, D. M., Loreau, M., Naeem, S., Schmid, B., Setälä, H., Symstad, A. J., Vandermeer, J. and Wardle, D. A. 2005. Effects of biodiversity on ecosystem functioning: A consensus of current knowledge. Ecological Monographs 75 (1) :3-35.

IPCC. 2006. Good Practice Guidelines for National Greenhouse Gas Inventories. Switzerland : Intergovernmental Panel on Climate Change (IPCC).

Malla, S. B., Rajbhandari , S. B., Shrestha, T. B., Adhikari, P. M., Adhikari, S. R. and Shakya P. R. 1986. Flora of Kathmandu Valley. Bull. Dept. Med. Plants Nepal, No. 11. Department of Medicinal Plants, Thapathali, Kathmandu, Nepal.

Naik, V. N. 1998. Taxonomy of Angiosperms. Tata McGraw-Hill Publishing Company Ltd, New Delhi, India.

Pande, P. R. 1967. Notes on Flora of Rajnikunj (Gokarna Forest). Bull. Dept. Med. Plants Nepal No. 1. Department of Medicinal Plants, Thapathali, Kathmandu, Nepal.

Press, J. R., Shrestha, K. K. and Sutton, D. A.. 2000. Annotated Checklist of the Flowering Plants of Nepal. The Natural History Museum, London, UK.

Roy, J. 2001. How does biodiversity control primary productivity? In Terrestrial global 
productivity (eds.) Roy, J., Sangier, B. and Mooney, H. A., San Diego, Academic Press.

Simpson, M. G. 2006. Plant Systematics. Elsevier academic press.

Spehn, E. M., Hector, A., Joshi, J., SchererLorenzen, M., Schmid, B., Bazeley-White, E., Beierkkuhnlein, C., Caldeira, M. C., Deimer, M., Dimitrakopolous, P. G., Finn, J. A., Freitas, H., Giller, P. S., Good, J., Harris, R., Högberg, P., Huss-Danell, K., Jumpponen, A., Koricheva, J., Leadley, P. W., Loreau, M., Minns, A., Mulder, C. P. H., O' Donovan, G., Otway, S. J., Palmborg, C., Pereira, J. S., Pfisterer, A. B., Prinz, A., Read, D. J., Schulze, E. -D., Siamantziouras, A. -S. D., Terry, A. C., Troumbis, A. Y., Woodyard, F. I., Yachi, S. and Lawton, J. H. 2005. Ecosystem effects of biodiversity manipulations in European grassland. Ecological Monograph 75 : $37-63$.

Stainton, J. D. A. 1972. Forests of Nepal. John Murray, London.

Stainton, A. 1988. Flowers of the Himalaya. A Supplement. Oxford University Press, New Delhi, India.
Subedi, B. P., Pandey, S. S., Pandey, A., Rana, E. B., Bhattarai, S., Banskota, T. R., Charmakar, S. and Tamrakar, T. 2010. Forest Carbon Stock Measurement : Guidelines for Measuring Carbon Stocks in Community-managed Forests. Published by ANSAB, FECOFUN, ICIMOD and NORAD, Nepal.

Suwal, P. N. 1969. Flora of Phulchoki and Godawari. Bull. Dept. Med. Plants of Nep. No. 2. Department of Medicinal Plants, Thapathali, Kathmandu, Nepal.

Waide, R. B., Willig, M. R., Steiner, C. F., Mittelbach, G., Gough, L.,Dodson S. I., Juday, G. P. and parmenter, R. 1999. The relationship between productivity and species richness. Annu. Rev. Ecol. Syst. 30 :257-300.

Weiner, J. and Thomas, S. C. 2001. The nature of tree growth and the "age-related decline in forest productivity". Oikos 94 (2): 374 376.

Zanne, A. E., Lopez-Gonzslez, G., Coomes, D. A., Ilic, J., Jansen, S., Lewis, S. L. and Chave, J. 2009. Towards a Worldwide Woods Economic Spectrum. Retrieved from http://hdl.handle.net/10255/dryad.235. 